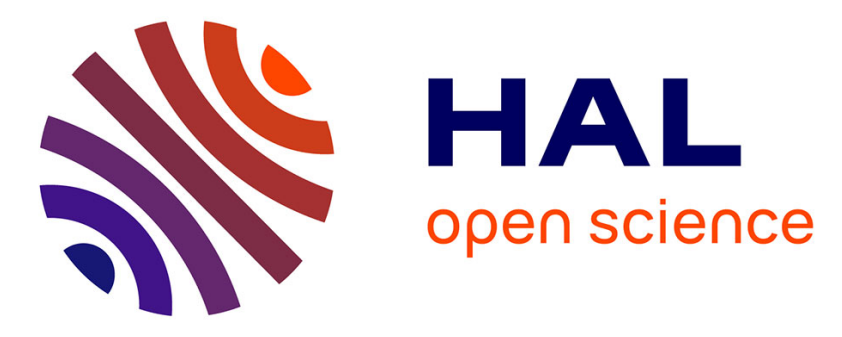

\title{
Parental alcohol dependence, socioeconomic disadvantage and alcohol and cannabis dependence among young adults in the community.
}

Maria Melchior, Marie Choquet, Yann Le Strat, Christine Hassler, Philip Gorwood

\section{To cite this version:}

Maria Melchior, Marie Choquet, Yann Le Strat, Christine Hassler, Philip Gorwood. Parental alcohol dependence, socioeconomic disadvantage and alcohol and cannabis dependence among young adults in the community.. European Psychiatry, 2011, 26 (1), pp.13-7. 10.1016/j.eurpsy.2009.12.011 . inserm00511782

\section{HAL Id: inserm-00511782 https://www.hal.inserm.fr/inserm-00511782}

Submitted on 26 Aug 2010

HAL is a multi-disciplinary open access archive for the deposit and dissemination of scientific research documents, whether they are published or not. The documents may come from teaching and research institutions in France or abroad, or from public or private research centers.
L'archive ouverte pluridisciplinaire HAL, est destinée au dépôt et à la diffusion de documents scientifiques de niveau recherche, publiés ou non, émanant des établissements d'enseignement et de recherche français ou étrangers, des laboratoires publics ou privés. 


\title{
Parental alcohol dependence, socioeconomic disadvantage
}

and alcohol and cannabis dependence among young adults in the community.

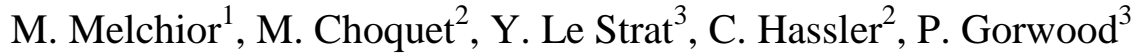

${ }^{1}$ INSERM U687, Villejuif, F-94807, France ; Université Paris XI, Villejuif, F-94807, France ; Hôpital Paul-Brousse, 16 avenue Paul Vaillant-Couturier, 94800 Villejuif, France Tél : +33 (0) 177747427 ; Fax : +33 (0) 177747403 ; email : maria.melchior@inserm.fr (Corresponding author)

${ }^{2}$ INSERM U669, Paris, France; Université Paris XI, Université Paris Descartes, UMR-S0669, Paris, France

Tél : + 33 (0) 158412850 ; email : marie.choquet@inserm.fr; christine.hassler@inserm.fr

${ }^{3}$ INSERM U675, Paris, France; Université Paris VI, Paris, France

Centre Psychiatrie et Neurosciences, 2ter rue d'Alésia, 75014 Paris, France

Tél : + 33 (0) 145657307 ; Fax: + 33 (0) 145658572 ; email : p.gorwood@ ch-sainte-anne.fr; yann.lestrat@inserm.fr

Keywords: alcohol dependence; cannabis; family history; socioeconomic position; young adults; epidemiology;

Abbreviations: SAGE (Susceptibility Addiction Gene Environment); CNIL (Commission Nationale Informatique et Liberté) ; DIGS (Diagnostic Interview for Genetic Studies) ; OR (Odds Ratio).

Word count : Abstract : 50

Manuscript (including tables and figures): 1656

Tables: 2

Figure: 1

References: 48 


\begin{abstract}
We tested the hypothesis that socioeconomic disadvantage exacerbates the intergenerational transmission of substance dependence. Among 3,056 community-based young adults (18-22 years, 2007), the prevalence of alcohol dependence (WHO AUDIT, 5.8\%) and cannabis dependence (DSM IV criteria, 7.3\%) was doubled in the presence of combined parental alcohol dependence and socioeconomic disadvantage.
\end{abstract}




\section{Introduction}

In industrialized countries, alcohol and illicit drug-related problems affect $5 \%$ of the population $(2 ; 19 ; 27)$ and cost $1-3 \%$ of gross domestic product (GDP) $(13 ; 17 ; 20 ; 21 ; 23)$, constituting a public health and societal challenge. Individuals with a family history of substance dependence are at high risk $(1 ; 28 ; 35)$; however, for reasons that are unknown, intergenerational transmission is heterogeneous, that is not all individuals with family history of substance dependence have substance-related problems themselves (48).

Using data from a community-based study, we test the hypothesis that intergenerational transmission of substance dependence varies with exposure to socioeconomic disadvantage, previously shown to predict alcohol and drug use disorders $(15 ; 16 ; 34)$. Parental substance-related problems are captured by history of alcohol dependence, the most frequent form of substance dependence $(2 ; 27)$ and a common correlate of illicit drug dependence (26). Analyses control for factors associated both with family socioeconomic and substance dependence characteristics and with youths' risk of alcohol and cannabis dependence, including immigrant status, history of sexual abuse (18), and mental health difficulties such as conduct disorder and depression (18;34).

\section{Material and Methods}

The SAGE (Susceptibility Addiction Gene Environment) study examines factors associated with psychiatric disorders and alcohol and drug use among young adults in France $(n=3,056$ youths in postgraduate training in North-Eastern France, March-April 2007, mean age: 20, sd: 1.4, 60.1\% male, 79\% response rate) (30). The study received approval from France's national body supervising ethical data collection (CNIL).

Alcohol dependence was assessed using the well-validated 10-item WHO AUDIT questionnaire $(7 ; 10)$ and defined as a score of $>=13$ (males) or $>=12$ (females). Cannabis dependence was assessed using a 10-item questionnaire derived from the Diagnostic Interview for Genetic Studies (DGIS) (37) and defined as >=3 symptoms among the 7 DSM IV criteria. This questionnaire is concurrent with a semi-structured clinical interview (30). 
Parental (mother's and father's) alcohol dependence was ascertained using the 13-item abridged version of the SMAST (Short Michigan Alcoholism Screening Test), which has good reliability and validity (14) and defined as >=3 symptoms (45). Participants with one or two parents with alcohol dependence had positive parental history (85.4\%: fathers, $12.6 \%$ : both parents).

Following previous research, socioeconomic disadvantage was ascertained as a composite of parental employment status and educational level (4;46) and defined as parental unemployment or $<$ secondary education.

Lifetime history of sexual abuse was ascertained using one item on attempted or completed unwanted sexual intercourse. Adolescent conduct disorder was measured using a self-report questionnaire derived from the DIGS $(37 ; 41)$ and defined as $>=3$ of the 15 DSM-IV criteria before age 15 (3). Current depression was assessed using the 10-item Adolescent Depression Rating Scale (ADRS) (43) and defined as $>=3$ positive symptoms. Immigrant status was defined as at least one parent born not in France (58.3\% in this group had two parents born abroad). Immigrant participants primarily came from North Africa (Algeria, Morocco, Tunisia: 38.6\%) or Europe (37.0\%), but due to insufficient statistical power we could not distinguish these subgroups in the analyses.

To test the hypothesis that socioeconomic disadvantage exacerbates the intergenerational transmission of alcohol and cannabis dependence, we created a combined measure of youths' familial risk (low risk: no parental alcohol dependence $n=2,476$; intermediate risk: parental alcohol dependence but no socioeconomic disadvantage $n=339$; high risk: parental alcohol dependence and socioeconomic disadvantage $n=69$ ). First, analyses were controlled for sex. Next, we additionally controlled for all covariates. Data were analyzed using logistic regression models in the SAS statistical software package (SAS V9, Carey, North Caroline).

\section{Results}

The prevalence rates of alcohol and cannabis dependence among study youths were $5.8 \%$ and $7.3 \%$ (correlation coefficient: 0.26 , p-value $<0.0001$ ). Youths whose parents had a history of 
alcohol dependence were more likely to have alcohol or cannabis dependence themselves (fullyadjusted ORs: alcohol dependence: 1.66, 95\% 1.20-2.48, cannabis dependence: $1.48,95 \%$ CI 1.022.15). Socioeconomic disadvantage was not independently associated with either study outcome (fully-adjusted ORs: alcohol dependence: $0.68,95 \%$ CI 0.38-1.23, cannabis dependence: 0.92, 95\%

CI 0.57-1.47). Table 1 shows youths' characteristics in relation to alcohol and cannabis dependence. As depicted in Figure 1, we observed a gradient-like association between familial risk and youths' alcohol or cannabis dependence. In sex-adjusted regression analyses (Table 2), a family history of alcohol dependence was associated with alcohol or cannabis dependence, especially in the presence of socioeconomic disadvantage (ORs: 2.64, 95\% CI 1.22-5.70 and 2.27, 95\% CI 1.10-4.70). In fully-adjusted analyses (Table 2), the ORs were decreased, however the likelihood of cannabis dependence in relation to high familial risk remained elevated and statistically significant. Formal tests of additive statistical interactions (44), conducted using a method proposed by Andersson et al. (5), showed that the Relative Excess Risk due to Interaction (RERI) between parental alcohol dependence and socioeconomic disadvantage was much different from 0 but did not reach statistical significance, probably due to a small number of cases (RERI: for alcohol dependence: $1.03,95 \%$ CI -0.99-3.06, for cannabis dependence: $0.48,95 \%$ CI -1.33-2.31).

\section{Discussion}

In a community-based sample, young adults with parental history of alcohol dependence were disproportionately likely to have alcohol or cannabis dependence, particularly if they experienced socioeconomic disadvantage. This social disparity in the intergenerational transmission of substance dependence partly reflected risk factors of substance dependence including history of sexual abuse and mental health difficulties. Addictive behaviors probably result from a combination of heritable and environmental risks and youths who cumulate both risks may be especially vulnerable.

The study's limitations are: 1) a sample of postgraduate students; 2) a cross-sectional design; 3) participant reports of parental alcohol dependence. In France, approximately $50 \%$ of youths 
achieve postgraduate training and our sample may not include individuals who experience severe socioeconomic hardship $(22 ; 38)$. Nevertheless, SAGE study participants represent diverse socioeconomic backgrounds and have levels of alcohol and cannabis disorders similar to national samples (31); thus our results should apply to other settings. Youths' substance-related problems are unlikely to predict parental alcohol dependence or socioeconomic disadvantage; however participants' reports may be influenced by substance use. Reassuringly, informant reports of substance dependence are highly specific (>90\%) (36) and our results are concurrent with those of prospective studies (1). Still, additional studies using multiple assessments of family history of alcohol and drug dependence would be useful.

Our study's main strength is a large sample of community-based young adults. The period of transition between adolescence and adulthood is key in the emergence of long-term patterns of substance abuse (11), yet young adults are difficult to include in epidemiological studies and data on this demographic group are few. Respectively $5.8 \%$ and $7.3 \%$ of study participants had alcohol and cannabis dependence, adding to evidence that a non-negligible proportion of youths does not desist from problematic substance use upon entering adulthood $(33 ; 39 ; 40)$. Youths' rates of substance use have increased in recent years $(8 ; 12)$ and better understanding of lifelong risk trajectories is needed.

Our study included immigrant youths, who are rarely studied in France (32). Compared to non-immigrants, this group had lower rates of alcohol dependence but comparable rates of cannabis dependence, implying specificity in substance use in relation to immigration status (25). Immigrants are disproportionately exposed to socioeconomic disadvantage, which justifies close monitoring of their health in a way that accounts for community of origin, conditions of migration, and acculturation in the host country (47).

In our study, the cumulative effect of parental alcohol dependence and socioeconomic disadvantage on youths' substance dependence was partly explained by risk factors such as history of sexual abuse, adolescent conduct disorder, and depression. The mechanisms linking familial 
context to these risk factors may include poor parenting $(6 ; 9 ; 24 ; 29)$ as well as high levels of family stressors such as financial difficulties, divorce or family conflict $(9 ; 42)$. Additionally, the intergenerational transmission of substance dependence may also reflect genetic influences, the expression of which may be enhanced in detrimental environmental conditions (1). It is also possible that parental alcohol dependence leads to family socioeconomic disadvantage; however, data needed to test test this hypothesis were not available in our study. In the future, the moderation of genetic risk of substance dependence by socioeconomic disadvantage should be tested.

\section{Conclusion}

Parents appear to have a lasting influence on their offspring's substance use well into adulthood. Improvements in families' socioeconomic conditions could reduce the transmission of substance dependence to the next generation. 
Acknowledgments: The authors thank the schools and youths who participated in the SAGE study. They also wish to express their gratitude to France Lert for her comments on a previous version of the manuscript and Hermann Nabi for methodological help. The SAGE study was funded by the Institut de Recherche sur les Boissons (IREB) and the Mission Interministérielle de Lutte contre la Drogue et la Toxicomanie (MILDT) in France. Maria Melchior is the recipient of a 'Young Researcher' award from France's Agence Nationale de la Recherche (ANR).

Conflict of interest: none. 
Table 1. Demographic, family and mental health characteristics of young adults in relation to alcohol and cannabis dependence: the SAGE study $(\mathbf{n}=\mathbf{2 , 8 8 4})$.

\begin{tabular}{|c|c|c|c|}
\hline & Prevalence (\%) & $\begin{array}{c}\text { Alcohol dependence } \\
\text { OR }(95 \% \text { CI })\end{array}$ & $\begin{array}{c}\text { Cannabis dependence } \\
\text { OR }(95 \% \text { CI })\end{array}$ \\
\hline \multicolumn{4}{|l|}{ Family characteristics } \\
\hline Parental alcohol dependence: Absent & 85.9 & 1.0 & 1.0 \\
\hline Present & 14.1 & $1.99(1.38-2.89)$ & $1.75(1.23-2.49)$ \\
\hline Socioeconomic disadvantage: Absent & 87.2 & 1.0 & 1.0 \\
\hline Present & 12.8 & $0.65(0.38-1.12)$ & $0.99(0.64-1.52)$ \\
\hline Familial risk ${ }^{1}$ : Low & 85.9 & 1.0 & 1.0 \\
\hline Intermediate & 11.8 & $1.91(1.28-2.87)$ & $1.67(1.14-2.46)$ \\
\hline High & 2.4 & $2.41(1.13-5.14)$ & $2.14(1.04-4.40)$ \\
\hline \multicolumn{4}{|l|}{ Demographic characteristics } \\
\hline Sex: Female & 40.5 & 1.0 & 1.0 \\
\hline Male & 59.5 & $3.32(2.22-4.96)$ & $2.03(1.47-2.80)$ \\
\hline Immigrant status: Immigrant & 21.4 & 1.0 & 1.0 \\
\hline Non-immigrant & 78.6 & $1.87(1.18-2.95)$ & $1.08(0.76-1.55)$ \\
\hline \multicolumn{4}{|c|}{ Mental health and experience of sexual abuse } \\
\hline History of sexual abuse: Absent & 97.0 & 1.0 & 1.0 \\
\hline Present & 3.0 & $1.97(0.97-4.00)$ & $2.43(1.32-4.47)$ \\
\hline Adolescent conduct disorder: Absent & 88.3 & 1.0 & 1.0 \\
\hline Present & 11.7 & $5.17(3.69-7.25)$ & $5.00(3.65-6.85)$ \\
\hline Depression: Absent & 78.8 & 1.0 & 1.0 \\
\hline Present & 21.2 & $1.81(1.29-2.55)$ & $2.18(1.21-3.93)$ \\
\hline
\end{tabular}

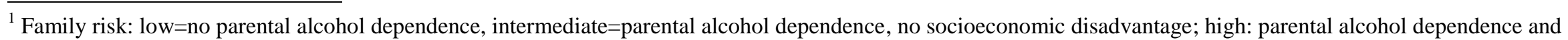
socioeconomic disadvantage.
} 
Table 2. Familial risk level in relation to alcohol and cannabis dependence among young adults: the SAGE study (logistic regression analysis OR, $95 \% \mathrm{CI})$

\begin{tabular}{|c|c|c|}
\hline & Alcohol dependence & Cannabis dependence \\
\hline $\begin{array}{c}\text { Sex-adjusted models }(\mathrm{n}=2884) \\
\text { Familial risk }^{1}: \text { Low } \\
\text { Intermediate } \\
\text { High }\end{array}$ & $\begin{array}{c}1.0 \\
2.09(1.39-3.15) \\
2.64(1.22-5.70)\end{array}$ & $\begin{array}{c}1.0 \\
1.77(1.20-2.60) \\
2.27(1.10-4.70)\end{array}$ \\
\hline $\begin{array}{c}\text { Sex: Female } \\
\text { Male }\end{array}$ & $\begin{array}{c}1.0 \\
3.46(2.31-5.18) \\
\end{array}$ & $\begin{array}{c}1.0 \\
2.09(1.57-2.89)\end{array}$ \\
\hline Fully-adjusted models $(\mathrm{n}=2851)$ & & \\
\hline $\begin{aligned} \text { Familial risk }^{1}: & \text { Low } \\
& \text { Intermediate } \\
& \text { High }\end{aligned}$ & $\begin{array}{c}1.0 \\
1.61(1.04-2.48) \\
2.06(0.88-4.82)\end{array}$ & $\begin{array}{c}1.0 \\
1.52(1.02-2.28) \\
1.43(1.62-3.32)\end{array}$ \\
\hline $\begin{array}{l}\text { Sex: Female } \\
\text { Male }\end{array}$ & $\begin{array}{c}1.0 \\
3.29(2.10-5.12)\end{array}$ & $\begin{array}{c}1.0 \\
1.96(1.37-2.81)\end{array}$ \\
\hline $\begin{array}{l}\text { Immigrant status: Immigrant } \\
\text { Non-immigrant }\end{array}$ & $\begin{array}{c}1.0 \\
2.19(1.36-3.53)\end{array}$ & $\begin{array}{c}1.0 \\
1.21(0.83-1.75)\end{array}$ \\
\hline $\begin{array}{r}\text { History of sexual abuse: Absent } \\
\text { Present }\end{array}$ & $\begin{array}{c}1.0 \\
2.42(1.10-5.31)\end{array}$ & $\begin{array}{c}1.0 \\
2.42(1.24-4.73)\end{array}$ \\
\hline $\begin{array}{r}\text { Adolescent conduct disorder: Absent } \\
\text { Present }\end{array}$ & $\begin{array}{c}1.0 \\
3.80(2.65-5.46)\end{array}$ & $\begin{array}{c}1.0 \\
3.81(2.72-5.33)\end{array}$ \\
\hline $\begin{array}{r}\text { Depression: Absent } \\
\text { Present }\end{array}$ & $\begin{array}{c}1.0 \\
1.83(1.26-2.64)\end{array}$ & $\begin{array}{c}1.0 \\
1.61(1.15-2.25)\end{array}$ \\
\hline
\end{tabular}

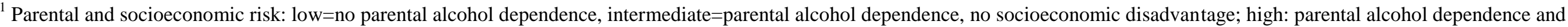
socioeconomic disadvantage. 
Figure 1 Prevalence of alcohol and cannabis dependence among young adults according to familial risk level: the SAGE study (\%).

A. Alcohol dependence

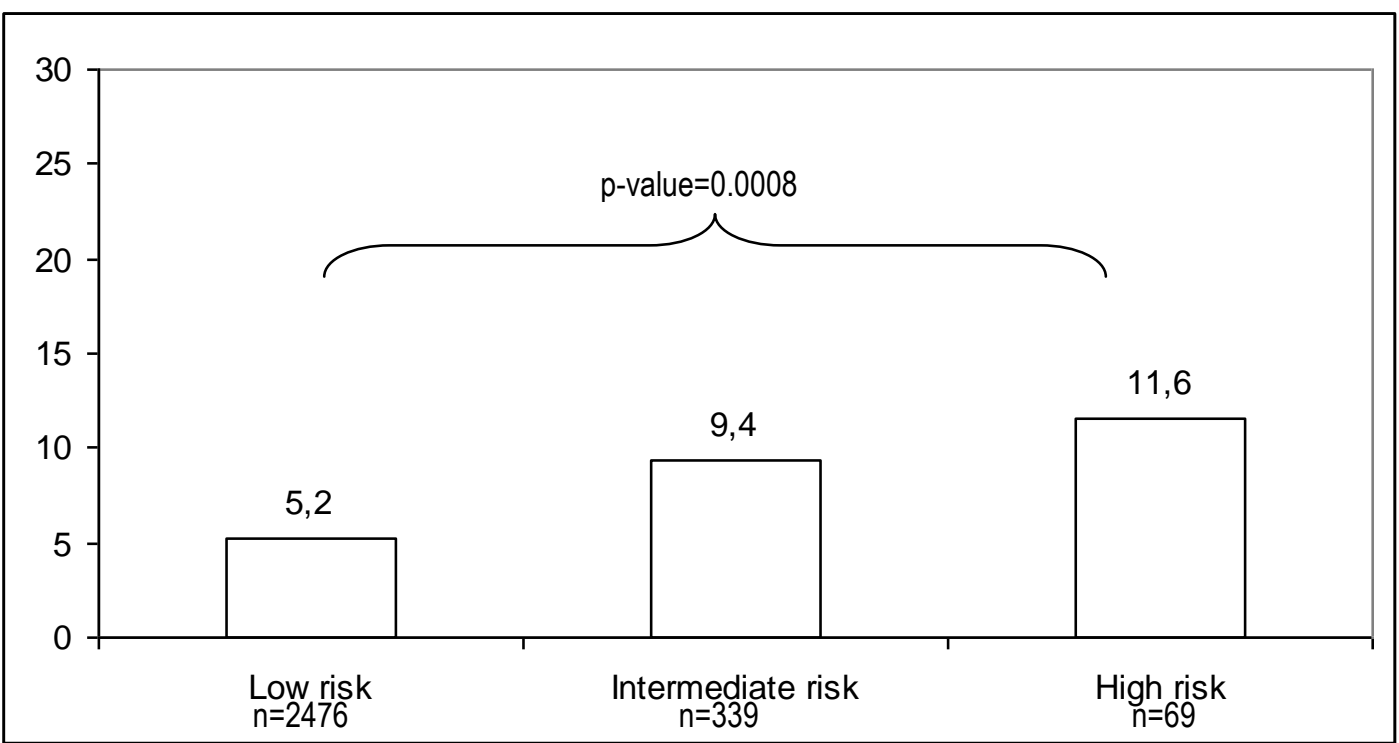

B. Cannabis dependence

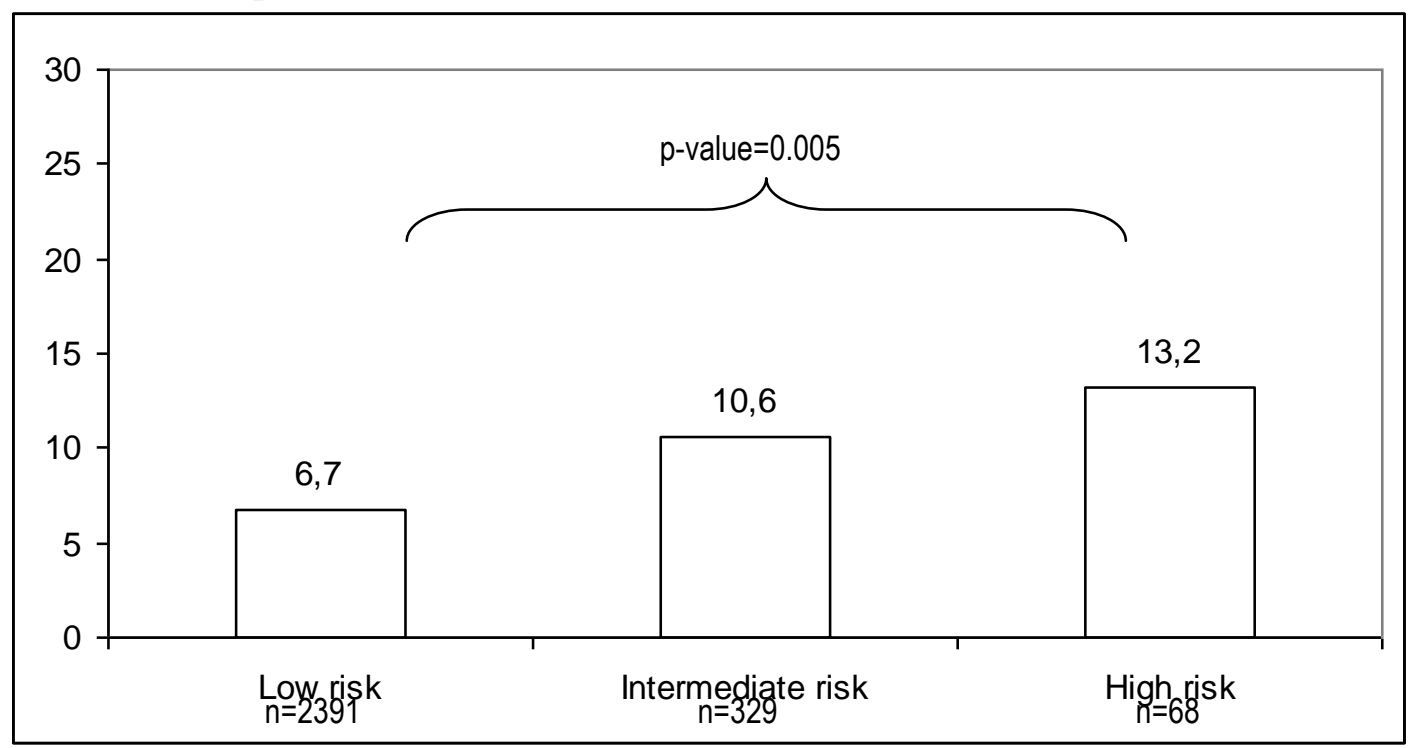

Low risk: no parental alcohol dependence Intermediate risk: parental alcohol dependence and no socioeconomic disadvantage

High risk: parental alcohol dependence and socioeconomic disadvantage 
(1) Agrawal A, Lynskey MT. Are there genetic influences on addiction: evidence from family, adoption and twin studies. Addiction 2008;103:1069-81.

(2) Alonso J, Angermeyer MC, Bernert S, Bruffaerts R, Brugha TS, Bryson H, et al. Prevalence of mental disorders in Europe: results from the European Study of the Epidemiology of Mental Disorders (ESEMeD) project. Acta Psychiatr Scand Suppl 2004:21-7.

(3) American Psychiatric Association. Diagnostic and statistical manual of mental disorders (Text revision 4th ed.). Washington,DC: American Psychological Association; 2000.

(4) Amone-P'olak K, Burger H, Ormel J, Huisman M, Verhulst FC, Oldehinkel AJ. Socioeconomic position and mental health problems in pre- and early-adolescents : The TRAILS study. Soc Psychiatry Psychiatr Epidemiol 2009;44:231-8.

(5) Andersson T, Alfredsson L, KH, Zdravkovic S, Ahlbom A. Calculating measures of biological interaction. Eur J Epidemiol 2005;20:575-9.

(6) Ashiabi GS, O'Neal KK. Children's health status: examining the associations among income poverty, material hardship, and parental factors. PLoS ONE 2007;2:e940.

(7) Babor T, Higgins-Biddle JC, Saunders JB, Monteiro MG. AUDIT: the Alcohol Use Disorders Identification Test. WHO 2007.

(8) Bachman JG, Johnson LD, O'Malley PM. Explaining recent increases in students' marijuana use: impact of perceived risk and disapproval, 1976 through 1996. Am J Public Health 1998;88:887-92.

(9) Bijttebier P, Goethals E, Ansoms S. Parental drinking as a risk factor for children's maladjustment: the mediating role of family environment. Psychol Addict Behav 2006;20:12630.

(10) Bohn MJ, Babor TF, Kranzler HR. The Alcohol Use Disorders Identification Test (AUDIT): validation of a screening instrument for use in medical settings. J Studies Alcohol 1995;56:423-32.

(11) Chen K, Kandel DB. The natural history of drug use from adolescence to the mid-thirties in a general population sample. Am J Public Health 1995;85:41-7.

(12) Choquet M, Morin D, Hassler C, Ledoux S. Is alcohol, tobacco, and cannabis use as well as polydrug use increasing in France? Addict Behav 2004;29:607-14.

(13) Collins DJ, Lapsley H. The costs of tobacco, alcohol, and illicit drug abuse to Australian society in 2004/2005. National Drug Strategy, 2008. [Available online]

(14) Crews TM, Sher KJ. Using adapted short MASTs for assessing parental alcoholism: reliability and validity. Alcohol Clin Exp Res 1992;16:576-84.

(15) Daniel JZ, Hickman M, Macleod J, Wiles N, Lingford-Hughes A, Farrell M, et al. Is socioeconomic status in early life associated with drug use? A systematic review of the evidence. Drug Alcohol Rev 2009;28:142-53.

(16) Droomers M, Schrijvers CT, Casswell S, Mackenbach JP. Occupational level of the father and alcohol consumption during adolescence; patterns and predictors. J Epidemiol Community Health 2003;57:704-10. 
(17) European Monitoring Centre for Drugs and Drug Addiction (EMCDDA). Annual Report 2007.

(18) Fergusson DM, Boden JM, Horwood LJ. The developmental antecedents of illicit drug use: evidence from a 25-year longitudinal study. Drug Alcohol Depend 2008;96:165-77.

(19) Hall W, Teesson M, Lynskey M, Degenhardt L. The 12-month prevalence of substance use and ICD-10 substance use disorders in Australian adults: findings from the National Survey of Mental Health and Well-Being. Addiction 1999;94:1541-50.

(20) Harwood H. Updating estimates of the economic costs of alcohol abuse in the United States: Estimates, update methods, and data. The Lewin Group, 2000.

(21) Harwood H. The Economic Costs of Drug Abuse in the United States: 1992-2002. The Lewin Group, 2004.

(22) INSEE. Taux de scolarisation des filles et des garçons à différents âges. 2006 [Available online].

(23) Institute for Alcohol Studies. Economic cost and benefits. 2008.[Available online]

(24) Jackson C, Henriksen L, Dickinson D. Alcohol-specific socialization, parenting behaviors and alcohol use by children. J Studies Alcohol 1999;60:362-7.

(25) Jayakody AA, Viner RM, Haines MM, Bhui KS, Head JA, Taylor SJ, et al. Illicit and traditional drug use among ethnic minority adolescents in East London. Public Health 2006;120:329-38.

(26) Kessler RC, Berglund P, Demler O, Jin R, Merikangas KR, Walters EE. Lifetime prevalence and age-of-onset distributions of DSM-IV disorders in the National Comorbidity Survey Replication. Arch Gen Psychiatry 2005;62:593-602.

(27) Kessler RC, Chiu WT, Demler O, Merikangas KR, Walters EE. Prevalence, severity, and comorbidity of 12-month DSM-IV disorders in the National Comorbidity Survey Replication. Arch Gen Psychiatry 2005;62:617-27.

(28) Korhonen T, Huizink AC, Dick DM, Pulkkinen L, Rose RJ, Kaprio J. Role of individual, peer and family factors in the use of cannabis and other illicit drugs: a longitudinal analysis among Finnish adolescent twins. Drug Alcohol Depend 2008;97:33-43.

(29) Latendresse SJ, Rose RJ, Viken RJ, Pulkkinen L, Kaprio J, Dick DM. Parenting mechanisms in links between parents' and adolescents' alcohol use behaviors. Alcohol Clin Exp Res 2008;32:322-30.

(30) Le Strat Y, Ramoz N, Horwood J, Falissard B, Hassler C, Romo L, et al. First positive reactions to cannabis constitute a priority risk factor for cannabis dependence. Addiction 2009 [Epub ahead of print].

(31) Legleye S, Beck F, Peretti-Watel P, Chau N. Usages de drogues des étudiants, chômeurs et actifs de 18-25 ans. Tendances, 2008.

(32) Lert F, Melchior M, Ville I. Functional limitations and overweight among migrants in the Histoire de Vie study (Insee, 2003). Rev Epidémiol Santé Publique 2007;55:391-400.

(33) Melchior M, Chastang J-F, Goldberg P, Fombonne E. High prevalence rates of tobacco, alcohol and drug use in adolescents and young adults in France: results from the GAZEL Youth study. Addict Behav 2008;33:122-33. 
(34) Melchior M, Moffitt TE, Milne BJ, Poulton R, Caspi A. Why do children from socioeconomically-disadvantaged families suffer from poor health when they reach adulthood? A lifecourse study. Am J Epidemiol 2007;166:966-74.

(35) Merline A, Jager J, Schulenberg JE. Adolescent risk factors for adult alcohol use and abuse: stability and change of predictive value across early and middle adulthood. Addiction 2008;103 Suppl 1:84-99.

(36) Milne BJ, Caspi A, Crump R, Poulton R, Rutter M, Sears MR, et al. The validity of the family history screen for assessing family history of mental disorders. Am J Med Gen Part B Neuropsychiatr Gen 2008;150B:41-9.

(37) Nurnberger JI, Jr., Blehar MC, Kaufmann CA, York-Cooler C, Simpson SG, HarkavyFriedman J, et al. Diagnostic interview for genetic studies. Rationale, unique features, and training. NIMH Genetics Initiative. Arch Gen Psychiatry 1994;51:849-59.

(38) OECD. Education at a glance. 2007. [Available online]

(39) Patton GC, Coffey C, Lynskey MT, Reid S, Hemphill S, Carlin JB, et al. Trajectories of adolescent alcohol and cannabis use into young adulthood. Addiction 2007;102:607-15.

(40) Perkonigg A, Goodwin RD, Fiedler A, Behrendt S, Beesdo K, Lieb R, et al. The natural course of cannabis use, abuse and dependence during the first decades of life. Addiction 2008;103:439-49.

(41) Preisig M, Fenton BT, Matthey ML, Berney A, Ferrero F. Diagnostic interview for genetic studies (DIGS): inter-rater and test-retest reliability of the French version. Europ Arch Psychiatry Clin Neurosci 1999;249:174-9.

(42) Pulay AJ, Dawson DA, Hasin DS, Goldstein RB, Ruan WJ, Pickering RP, et al. Violent behavior and DSM-IV psychiatric disorders: results from the national epidemiologic survey on alcohol and related conditions. J Clin Psychiatry 2008;69:12-22.

(43) Revah-Levy A, Birmaher B, Gasquet I, Falissard B. The Adolescent Depression Rating Scale (ADRS): a validation study. BMC Psychiatry 2007;7:2.

(44) Rothman KJ, Greenland S. Modern epidemiology. 2 ed. Philadelphia: Lippincott-Raven; 1998.

(45) Selzer ML, Vinokur A, van Rooijen L. A self-administered Short Michigan Alcoholism Screening Test (SMAST). J Stud Alcohol 1975;36:117-26.

(46) Trzesniewski KH, Moffitt TE, Caspi A, Taylor A, Maughan B. Revisiting the association between reading achievement and antisocial behavior: new evidence of an environmental explanation from a twin study. Child Development 2006;77:72-88.

(47) Uniken Venema HP, Garretsen HF, van der Maas PJ. Health of migrants and migrant health policy, The Netherlands as an example. Soc Sci Med 1995;41:809-18.

(48) VanVoorst WA, Quirk SW. Are relations between parental history of alcohol problems and changes in drinking moderated by positive expectancies? Alcoholism: Clin Exp Res 2003;27:25-30. 